\title{
FATHOM
}

\section{Of Gargoyles and Men: Creative Vitality in Far from the Madding Crowd}

Des gargouilles et des hommes : la notion de vitalité créatrice dans Far from the Madding Crowd

\section{Isabelle Gadoin}

\section{OpenEdition}

\section{Journals}

Electronic version

URL: http://journals.openedition.org/fathom/577

DOI: $10.4000 /$ fathom.577

ISSN: 2270-6798

\section{Publisher}

Association française sur les études sur Thomas Hardy

Electronic reference

Isabelle Gadoin, "Of Gargoyles and Men: Creative Vitality in Far from the Madding Crowd ", FATHOM

[Online], 3 | 2016, Online since 30 April 2016, connection on 19 April 2019. URL : http://

journals.openedition.org/fathom/577 ; DOI : 10.4000/fathom.577 


\title{
Of Gargoyles and Men: Creative Vitality in Far from the Madding crowd
}

\author{
Des gargouilles et des hommes : la notion de vitalité créatrice dans Far from the \\ Madding Crowd
}

Isabelle Gadoin

1 It is widely acknowledged that Thomas Hardy's first training as an architect was crucial to the development of his career as a novelist. Yet the relationship between architecture and the very substance and structure of Hardy's novels does not seem to have been as thoroughly researched as other, more discursive, aspects of his literary production. It is most striking that the critics who chose to analyse the "Gothic" flavour of his writings have almost unanimously taken the term "Gothic" in its literary extensions rather than in the primarily architectural sense of the word - a good case in point being James F. Scott's by-now classic 1963 article on "Thomas Hardy's Use of the Gothic: An Examination of Five Representative Works". Scott's introduction seems to take it for granted that "Gothic" is nothing more than a term of literary criticism. The reasons he puts forward for his choice of the word "Gothic" seem to reduce its scope dramatically by making it nothing more than a synonym - though slightly more neutral, he says - of the adjectives "sensationalist" and "melodramatic" - two notions clearly belonging to the field of narrative analysis (Scott 364). The word "Gothic", Scott goes on to explain as a second motivation for his choice, allows us to put the question of the "realistic" versus "symbolic" effects of Hardy's writing; finally, Scott explains in what he surely regards as his most powerful argument, the word "Gothic" sends us back to a rich literary tradition "which flourished early in the nineteenth century and fragments of which survived into Hardy's own time" (Scott 364). One could not say more explicitly that the intellectual background of the study is that of purely literary history, in which "Gothic" does not seem to go much further back in time than the early nineteenth century, in a rather unexpected and highly flattened overview of artistic history... This same defect was 
already present in Richard Carpenter's slightly earlier article on "Hardy's 'Gurgoyles", which altogether dispensed with any sort of historical definition of what was nevertheless the central notion of "grotesqueness". Carpenter merely stated that "[a]s Webster says, the grotesque consists in mixing up natural imagery (flowers, foliage and men) with conventional designs and figures (scrolls, garlands, satyrs...)" (Carpenter 226). This type of literary bias finally resurfaces in Brigitte Hervoche-Bertho's far more recent article "Seminal Gothic Dissemination in Hardy's Writings", which posits from the start, very much in echo of Scott's demonstration, that Hardy's most striking images were inspired by his taste for "macabre folktales", or "the legends and ballads of his native Dorset" (Hervoche-Bertho 451). To be quite fair, B. Hervoche-Bertho makes very perceptive use of the notions of the macabre and the grotesque, as tools of literary analysis but without using the history and concepts of aesthetics to probe into the visual dimension of Hardy's text.

One has to grant that looking for Hardy's views of architecture through his literary productions is no easy task. Although he did infuse his architectural knowledge within the always very minute and highly visual descriptions of the buildings and monuments in his novels and short stories, he never expatiated in his fiction on his conception of architecture, as he was to do in his more public writings and speeches in the later part of his career. On reading the description of the gargoyle of the Weatherbury Church in Far from the Madding Crowd, I had the feeling that this was the closest he ever came in his novels to a theoretical statement of intentions as far as architecture was concerned; and I shall use it as a basis to try and attempt a more formal reading of Hardy's visual aesthetics, by placing these back within the context of art-historical discourse in the second half of the nineteenth century. Then, coming back to Hardy's gargoyle, I will show that it is not simply one of the elements in the machinery of the plot, but that it is the vector for Hardy's aesthetics and, beyond that, for what may be perceived as a philosophical investigation into man's place in a cold and largely hostile universe.

The description of the gargoyle opens on a strictly realistic mode, to which one could easily apply Philippe Hamon's analytical categories. The whole of the first paragraph in chapter 46 seems to unfold logically from the kernel-phrase "The tower of Weatherbury Church", which works as the "hyperonym", or "pantonym", in Hamon's terminology (Hamon 141 sq.), containing in germ the whole of what is to follow (Hardy 1986, 241). The shape of the tower ("square"), the date of its erection (" $14^{\text {th }}$ century" - in other words, long before the $19^{\text {th }}$-century vogue for Gothic fiction), and the exact distribution of sculpted ornaments over the surface of the tower: all these basic elements of definition are encapsulated within the sentence opening the chapter. The rest of the paragraph carries on in the same definitional mode, based on the multiplication of such expert words as "gargoyles", "parapet", "carved protuberances", which will be taken up in the next paragraph and qualified with the proper technical adjectives, like "ornamental parapet", "prominent [gargoyles]", "original design", etc.

Yet the second paragraph suddenly moves away from this strictly descriptive mode to a more speculative tone, strangely conjoining universal assertion and dialogical allusions: "It has sometimes been argued that there is no truer criterion of the vitality of any given art-period than the power of the master-spirits of that time in grotesque; and certainly in the instance of Gothic art there is no disputing the proposition" (Hardy 1986, 241). In his article on Hardy's 'Gurgoyles' Richard Carpenter quotes this passage without dwelling on it; but it seems to me that the binary structure of the sentence suggests an implicit 
dialogue that calls for attention. It is balanced between the introductory formula "It has sometimes been argued" and the conclusive concession "certainly [...] there is no disputing [it]", as if moving clearly from the initial hypothesis or "proposition" of some unidentified speaker to its final acceptation or confirmation by Hardy's narrator. But, one will ask, who was the anonymous interlocutor Hardy was implicitly referring to and holding private conversation with? Once you have asked yourself the question, you cannot help reading the whole passage as a general treatise on the characteristics and value of Gothic, and not only as a careful description of the Weatherbury Church tower. And the name that first springs to mind is that of the most ardent supporter of Gothic art in Victorian times, that is, John Ruskin. So, although the name is not uttered, I will try and show that many elements argue in favour of a "Ruskinian" reading both of that precise passage, and of the novel at large.

Before entering into the argument, I have to say I am aware of treading on rather unstable ground. Thanks to Michael Millgate's exhaustive inventory of the books in Hardy's personal library at Max Gate (see Millgate), we know that the writer owned an edition of Ruskin's essay on The Nature of Gothic - A Chapter of the Stones of Venice, in the beautifully illuminated version printed by William Morris's Kelmscott Press in 1892 (as well as several other books by Ruskin, most of them selections and anthologies). But this particular edition was obviously published long after he wrote Far from the Madding Crowd, and it is difficult to trace Ruskin's possible influence in his early life and career. Strange as it seems, there are very few explicit mentions of John Ruskin in Hardy's own writings or in the biographical or critical studies of his work. In her biography of Hardy, Claire Tomalin shows him as a young man, discovering the fine arts and London's National Gallery probably after reading Ruskin's Modern Painters, on the suggestion of his fellowtrainee, the architect Philip Shaw and later, as a mature and recognised man of letters, dining in London with an intellectual circle that included John Ruskin-among so many others (Tomalin 67). Ralph Pite's incidental mentions of Ruskin, in what is to this day the most recent biography of Hardy, are never directly connected with the novelist's intellectual development. What is even stranger is that neither Martin Seymour-Smith nor Michael Millgate, the most distinguished and renowned of all Hardy's biographers, seem to mention Ruskin even once-at least if one is to believe the information given by the indexes of their works... J. B. Bullen, in his extensive study of "Hardy and the Visual Arts", does allude to Hardy's early reading of Ruskin, and yet his reference is based on indirect testimony and partly hypothetic assertions: "As early as 1862 Hardy had told his sister that he was reading Ruskin's Modern Painters, and as a young architect he could not have failed to have read The Seven Lamps of Architecture and The Stones of Venice" (Bullen 23, 192, 253). Symptomatically, J. B. Bullen goes on to note that "Hardy rarely mentions Ruskin by name, but his literary notes show that, during his life, he frequently turned to Ruskin's views in the nature of perception, or his ideas about verisimilitude in painting and literature" (Bullen 23, my emphasis).

6 Thus, while it is hard to trace precise references to Ruskin in Hardy's writings, his fiction and personal reflexions unfold within a truly Ruskinian intellectual and artistic atmosphere, as hinted by Bullen. Hardy's (auto)-biography is almost silent on the subject, with only six mentions of Ruskin in total. Yet judging by the tone of these references, one can hardly be left in any doubt as to Hardy's intimate relationship to the great art critic's work and ideas. On the contrary, the novelist must have been so familiar with these that, in travelling to Venice, or even to Switzerland, he seems to have taken Ruskin as a guide 
- one is tempted to say as a tourist-guide - and as a gauge, constantly weighing his own experience in comparison to the "advice" or "recommendations" of the great master. Thus, in Venice, Hardy notes "they [i.e. the novelist and his wife] had been unable to follow Ruskin's excellent advice of approaching Venice by water" (Hardy 1989, 203). In Lausanne, he remembers, they stopped at the "Hôtel Gibbon", "Hardy not having that aversion from the historian of The Decline and Fall that Ruskin recommended" (Hardy 1989, 311).

7 More apposite to my demonstration is the fact that, in alluding to Ruskin in his (auto)biography, Hardy uses exactly the same type of polemical or judgemental tone as was noted in the presentation of the gargoyle of the Weatherbury Church: Ruskin is referred to, either to prove or disprove, to confirm or infirm, Hardy's point. Here is Ruskin winning approbation: "What Ruskin says as to the cause of the want of imagination in works of the present age is certainly true" (Hardy 1989, 179). Here, on the other hand, is Ruskin being savagely criticised: "There is surely some conventional ecstasy, exaggeration - shall I say humbug? - in what Ruskin writes about [St Mark's in Venice], if I remember, though I have not read him lately" (Hardy 1989, 201). It is quite telling that, while making these allusions rather casually, as if in passing, Hardy is always careful to position himself in relation to the great writer, as if avid to win or to clinch the argument... So I would tend to think that the scarcity of explicit mentions of Ruskin in Hardy's work as well as in critical analyses comes not from ignorance but rather, on the contrary, from the fact of his perfect acquaintance with Ruskin's writings and theses, as evidenced by his confessional aside "if I remember, though I have not read him lately". For an architect trained in the mid-nineteenth century, when the movement of Gothic Revival was in full swing, it is most probable that Ruskin literally went without saying...

So I propose to read the thoughts and considerations on the Weatherbury gargoyle as entirely (though possibly unconsciously) subtended by Ruskinian theories on Gothic architecture. The key notion in Hardy's quick allusion to Gothic art in Far from the Madding Crowd is that of "vitality". This appears to be Hardy's own word, since Ruskin rather speaks of the life of a work of art - a notion he first developed at length in the chapter on "The Lamp of Life" in The Seven Lamps of Architecture (1849). Yet Hardy's notion of "vitality" actually encompasses the whole of Ruskin's theory and praise of Gothic, which then found its passionate expression in the well-known chapter on "The Nature of Gothic" (Book II, chapter VI) in The Stones of Venice.

9 As opposed to all the analysts who endeavoured to list and detail all the individual features of a work of art, Ruskin put it as a prerequisite that all the constituent elements of a building should cohere together into an almost organic - or should we say "vital" form: "Pointed arches do not constitute Gothic, nor vaulted roofs, nor flying buttresses, nor grotesque sculptures; but all or some of these things, and many other things with them, when they come together so as to have life" (Ruskin 1891, 152). From that initial proposition, the rest of the chapter only seeks to trace the exact source of that life. It is to be found, Ruskin next says, in the tight union of "Material Form" and "Mental Expression": "It is not enough that it [architecture] has the Form, if it have not also the power and life. It is not enough that it has the Power, if it have not the form" (Ruskin 1891, 153). The core of Ruskin's argument, as is well known, is that this "expression" or "life" will never be infused into a work of art if the worker is not left free to follow the most instinctive movements and passions of his soul. Ruskin thus puts the premium on the worker's untrammelled inventiveness, which he merely calls "invention", as if to 
closely echo the classical Italian concept of inventio. "Always look for invention first", is Ruskin's dictate (167.)

What follows is Ruskin's famous, and most provocative, crusade against perfection which he from the start devalues as a mere mechanical aggregate of "perfectnesses", in a striking plural form which radically disseminates and defuses the impact of the very notion of perfection: "accurate mouldings", "perfect polishings", "unerring adjustments", all these "perfectnesses are signs of a slavery" (Ruskin 1891, 167). Indeed, if the worker is made to copy perfect models in a servile way, by never-endingly repeating pre-ordained series of precise gestures which involve no personal intervention or active imagination, then he becomes a mere tool himself, his soul being denied and even "smothered" within him (162). This is "the degradation of the operative into a machine" (163), which opens the central and most vocal part of Ruskin's diatribe against the modern idea of the division of labour. For this, he holds, is nothing else than the division of men themselves into mechanical parts:

You must either make a tool of the creature, or a man of him. You cannot make both. Men were not intended to work with the accuracy of tools, to be precise and perfect in all their actions. If you will have that precision out of them, and make their fingers measure degrees like cog-wheels, and their arms strike curves like compasses, you must unhumanise them. All the energy of their spirits must be given to make cogs and compasses of themselves. (Ruskin 1891, 161)

Conversely, deficiencies, irregularities, constant change, and even imperfections will become valuable as the direct trace or "expression" of the worker's free inventiveness-in other words as so many signs of life or vitality. Extending this into a more global type of aesthetics, one might wonder if it is not possible to see here one of the sources for Hardy's claim that art should be "a disproportioning" or a way of seeking "beauty in ugliness" (Hardy 1989, 222). Even Hardy's interest in "rustic" characters, who assuredly show more liveliness than perfection, could already be foreseen in Ruskin's praise of coarse but sincere workers: "Let them show their weaknesses together with their strengths" (Ruskin 1891, 170). In truth, Hardy's novels might stand as an apt illustration of Ruskin's plea: "Only get the thought, and do not silence the peasant because he cannot speak good grammar" (167).

In Ruskin's theory then, vitality is the true criterion, which he pushes so far as to come to what he calls the "fantastic paradox" of a conclusion, that "no architecture can be truly noble which is not imperfect" (Ruskin 1891, 170; Ruskin's emphasis.) For, to come full circle, "that imperfection is in some sort essential to all that we know of life. It is the sign of life in a human body, that is to say, of a state of progress and change [...] And in all things that live there are certain irregularities and deficiencies which are not only signs of life, but sources of beauty [...] [T]o banish imperfection is to destroy expression, to check exertion, to paralyse vitality" (171, my emphasis).

For Ruskin, this "vitality" is best seen in the architecture of the North, with its "wildness of thought", "roughness of work" and overall "energy" (Ruskin 1891, 158). And the creations Ruskin evokes as products of that "wild and wayward" Northern imagination cannot fail to recall Hardy's very vivid description of the Weatherbury gargoyle. They belong to the same family of grotesque ornaments, "creatures of ungainly shape and rigid limb, but full of wolfish life; fierce as the winds that beat, and changeful as the clouds that shade them" (157). Here again, as in Hardy's sweeping evocation, the one criterion of quality is that of "life" or "vitality": "examine once more those ugly goblins, and formless 
monsters, and stern statues, anatomiless and rigid; but do not mock at them, for they are signs of the life and liberty of every workman who struck the stone" (163, my emphasis).

The similarity between those ugly goblins and Hardy's gargoyle is not only a surface one. The Weatherbury gargoyle seems to answer the six defining qualities which Ruskin enumerated at the very start of his chapter on Gothic architecture and ornament: "1. Savageness, 2. Changefulness, 3. Naturalism, 4. Grotesqueness, 5. Rigidity, 6. Redundance" (Ruskin 1891, 154). Hardy's "horrible stone entity", with its cruel laughter, no doubt has the "savageness" first required by Ruskin. But the narrator is also careful to insist on the principles of both "redundance" and "changefulness", by showing the gargoyle as globally similar, yet far more impressive than its other carved counterparts: "All the eight were different from each other. A beholder was convinced that nothing on earth could be more hideous than those he saw on the north side until he went round to the south. Of the two in this latter face, only that at the south-eastern corner concerns our story" (Hardy 1986, 241). As in the first paragraph of the chapter, Hardy seems to stress the perfect arithmetical distribution of the ornaments - two on each of the four sides of the tower - only to emphasize that distortion in their symmetry (or, in Hardy, "that symmetry in their distortion") which finally destroys the initial feeling of perfect regularity and proportions... The gargoyle is also "rigid", at the same time as "naturalistic", since its limbs and traits are both animal (with its "wrinkled hide") and human (with its ears, mouth and teeth, as well as toes). Finally it is this hybrid nature, borrowing from all three realms, animal, vegetal and human, that also qualifies it as an archetypal sample of "grotesque" ornament.

To Ruskin the grotesque is one of the late stages of development that rushed Gothic art on the downward curve of degeneracy. Yet the mixture of fascination and repulsion which he expresses on discovering the grotesque head ornamenting one of the late Renaissance monuments of Venice sets the exact note for what will be Hardy's description of the Weatherbury gargoyle:

A head - huge, inhuman, monstrous - leering in bestial degradation, too foul to be either pictured or described; or to be beheld for more than an instant; yet let it be endured for that instant; for in that head is embodied the type of the evil spirit to which Venice was abandoned in the fourth period of her decline; and it is well that we should see and feel the whole horror of it on this spot, and know what pestilence it was that came and breathed upon her beauty, until it melted away like the white cloud from the ancient fields of Santa Maria Formosa. (Ruskin 1891, 121)

16 In direct echo of Ruskin's professed incapacity to either "picture or describe" the grotesque head, Hardy seems to be groping for words in his evocation of the gargoyle. His most suggestive sentence indeed relies on approximation, comparison, and assertion constantly denied and reformulated, in a cascade of tentative definitions: "It was too human to be called a dragon, too impish to be like a man, too animal to be like a fiend, and not enough like a bird to be called a griffin". What was straightforwardly "bestial" in Ruskin's "picture" has become in Hardy an unbearable confusion of animal and human features. But in both texts alike it is the evil potential of the creature that is seized at first sight and inspires the beholder with an intense "horror". And in both cases, the barbarous creature seems to exhale this "evil" in a most physical and aggressive way, by "breathing" it, in Ruskin's words, or "vomiting” it, in Hardy's. Finally the reader acquainted with Hardy's novel will not miss the word "pestilence" in Ruskin's text, since this very word will come to qualify the nauseating emanations of the rotting swamp where Bathsheba will briefly buries herself after her discovery of Troy's felony. 

comes to life, and seems in the end to be moved by some evil vitality, as shown by the "ing" forms that close the whole of Hardy's paragraph: "The creature had for four hundred years laughed at the surrounding landscape, voicelessly in dry weather, and in wet with a gurgling and snorting sound" (Hardy 1986, 241). Likewise, it was the active and offensive expression of wickedness that made Ruskin shiver in front of the Venetian carved head: "The head is one of many hundreds which disgrace the latest buildings of the city, all more or less agreeing in their expression of sneering mockery, in most cases enhanced by thrusting out the tongue" (Ruskin 1891, 121). In both cases, what should have remained mere ornament has become an almost purposive agent of aggression on the beholders or the passers-by, as Troy will unfortunately experience...

In Hardy's novel, however, the vital principle which Ruskin and later defenders of Gothic art sought to perceive in architecture, is not only illustrated by the gargoyle of the Weatherbury Church. It is one of the constant determinants of Hardy's buildings that they seem to be animated with a life of their own. The evocation of Bathsheba's manor seems to bring together the Ruskinian principle of "vitality" with the Darwinian notion of "adaptation", which both help to turn the building into a living organism. The house is first endowed with human feelings thanks to the process of hypallage (which makes it either "sleepy" or "animated"), and then becomes purely and simply a body, which has been able to grow and adapt to new circumstances: "[...] the generally sleepy air of the whole prospect here, together with the animated and contrasting state of the reverse façade, suggested to the imagination that on the adaptation of the building for farming purposes the vital principle of the house had turned inside its body to face the other way" (Hardy 1986, 59-60).

The same type of vitality, though heard in a more religious than Darwinian sense this time, can be found in the Great Barn. Again, the Barn is metaphorically presented as a body that has suffered no "mutilation at the hands of time" (Hardy 1986, 113), but which has "grown" and transformed, so that what was at first a static "picture of to-day in its frame of four-hundred years ago" finally puts on a most expressive type of appearance: "in Weatherbury three or four score years were included in the mere present, and nothing less than a century set a mark on its face or tone" (114). Needless to say, the Great Barn is just as welcoming a face as the gargoyle's is repulsive... Hardy's almost "militant" description of the Barn enforces exactly Ruskin's point that architectures may be noble precisely because they are not perfect, and because on the contrary they show all the wear and tear that is the sign of a long and rich history: its floors, "black with age and polished with the beatings of flails for many generations" appear just as noble and impressive as "the state-room floors of an Elizabethan mansion" (114). And the reasoning could be extended to the humblest dwellings, like the malthouse, with its "wild" and "rough" architecture, to take up Ruskin's words (44-45). But for all its irregularities, its "sloping" roofs and "undulating" floors, the malthouse clearly has a "Mental Power" and "Expression" that more "perfect" buildings would sorely miss.

However not all monuments in Weatherbury thus acquire vital force, whether creative or simply adaptive. The Barracks where Troy is first stationed never appears as anything else than a simple "mass", the only features of which are "verticality" and "darkness" (Hardy 1986, 70). Far from ever acquiring any sort of vitality it seems on the contrary to seep away all the vigour and life of those who approach it. Under the windows of the barracks, Fanny is no more than a mere shadow on a wall or a dark spot on the snow. In

FATHOM, 3 | 0000 
the dialogue that follows, the obnoxious influence of the place weighs so heavily on the speakers as to simply erase them. Through the process of metonymic contiguity, their dialogue is turned into an abstract exchange between the wall and the river. This cold, forbidding block of a building will find its deadly counterpart in the Workhouse where Fanny dies. This was built for strictly utilitarian purposes, the exact opposite of any spirit of creation or inventiveness: "Originally it had been a mere case to hold people" (207). This is therefore a place without a soul, a place without "Mental Expression"-so antithetical with the notion of life and vitality that it can only herald the coming death of Fanny. While Bathsheba's manor-house and the Great Barn appeared as living bodies, the Union House, on the contrary, reminds one of the coffin or the shroud waiting for some corpse to be deposited there: "The shell had been so thin, so devoid of excrescence, and so closely drawn over the accommodation granted that the grim character of what was beneath showed through it, as the shape of a body is visible under a winding-sheet (207). Only Nature will succeed in redeeming the ugly building, by covering the cold stone with a "magnificent" coat of ivy...

21 Although ugly and dead, these two examples of the barracks and the Union house should not be neglected when speaking of Hardy's architectures, for they, just as much as Bathsheba's manor-house and barn, show the indivisibility of character and environment. So tight is this interaction between man and his living-place that we could re-read the whole of the narration, applying the criterion of "vitality" to the characters as well as to the buildings housing them. It would be easy to show that Bathsheba irrupts into the narrative in a quick series of scenes designed to show her vigour and indefatigable energy, as in her riding exercise, where animal imagery serves to reinforce this impression of natural life. Fanny on the other hand enters the story as Bathsheba's clear foil, with all her vital forces apparently exhausted from the start, as Oak can feel in her febrile pulse. This identification of man with his surroundings is soon so complete that the buildings not only reflect the vitality of their inhabitants but may even come to foreshadow their destiny, as the reader is made to understand when Fanny approaches the fatal end of her existence at the Union House...

The gargoyle is no doubt the most potent symbol of this indissociability of character and environment. Not only does it warn us of the ineluctable failure of Troy's pathetic efforts of redemption on Fanny's tomb, it also appears to enact his condemnation actively. Like the awful head Ruskin hardly dared look at, the gargoyle seems to delight in the contemplation of human vice and weaknesses, and its laughter becomes what Ruskin called "the expression of sneering mockery" and of "low sarcasm" at human frailty (Ruskin 1891, 121). But the most unsettling thing is that this sardonic laughter which ends up triumphing in the scene of "Fanny's Revenge" actually keeps ringing throughout the book, as a poetic motif disseminating the sense of man's powerlessness in the hands of a jeering Fate. In a very troubling way, Troy was the first to apparently laugh at Fate. When he closes the window upon Fanny at the barracks after their first embarrassed dialogue in the novel, it is to burst into a cruel mocking "expostulation", amid "a peal of laughter, which was hardly distinguishable from the gurgle of the tiny whirlpools outside" (Hardy $1986,72)$. The reader can hardly fail to sense in the close association of the laugh and the sound of "gurgling" water a condensed suggestion of the famous scene of the gargoyle's revenge, with its burbling sounds. More than its visual traits, it is finally the hollow reverberated echoes of the splash of water that turns the gargoyle into a sarcastic agent of Nemesis. 

the dry hollow laughter of Fate everywhere around Troy. It is first of all the congregation of villagers who seem to giggle at the bridegroom waiting in vain for his bride. But the laughter becomes far more cruel when it is relayed and amplified by the "grotesque clockwork" of the tower, the description of which is just as blood-curdling as Ruskin's grotesque head: "One could be almost positive that there was a malicious leer upon the hideous creature's face, and a mischievous delight in its twitchings" (Hardy 1986, 92). The scene is grotesque in the proper sense that it radically blurs the difference between object and subject, between humanity and inhumanity, and between man and the active forces surrounding him... Yet Troy still goes on in his defiant way, and when Fanny rushes in, desperate and repentant after mistaking the two churches of All Saints' and All Souls', he merely brushes her supplications aside with "a hoarse laugh" (92). Finally, in a highly dramatised scene, it is this proud and defiant laughter of the cold and indifferent "trickster" which will identify him when he comes back to claim Bathsheba as his wife, right in the midst of Boldwood's Christmas party: "Troy began to laugh a mechanical laugh: Boldwood recognised him now" (289). In this strange (and grotesque) cross-over where roles are constantly redistributed and reversed, Troy himself seems to have turned into the "malicious" automaton which we had first glimpsed within the church of All Saints'... Seen in this light, the gargoyle may be taking revenge indeed - but it is only the natural retaliation of Fate against the character who has thought all the while that he could mock others and laugh at events, ignoring or defying his Destiny.

Once the reader is made aware of the sad philosophical implications of that cold, sardonic laughter, it starts ringing though the whole of Hardy's work, and not only in individual novels. In The Return of the Native, Clym Yeobright cannot retain a "ghastly" laugh when trying to force out a confession on the part of his wife Eustacia, after realizing she has long had a lover.

[...] 'It seems that my wife is not so very well?

'Why?'

'Your face, my dear, your face. Or perhaps it is the pale morning light which takes your colour away? Now I am going to reveal a secret to you. Ha-ha!'

' $\mathrm{O}$, this is ghastly!'

'What?'

'Your laugh.'

'There is reason for ghastliness, Eustacia. You've held my happiness in the hollow of your hand, and like a devil, you've dashed it down!' (Hardy 2006, 270; my emphasis)

Interestingly, the scene empties the dialogue of any form of feeling and humanity by decomposing Eustacia's face into a blank unreadable surface, or an empty mask, and by turning Clym's words into incomprehensible laughter - a laughter that makes him an almost devilish agent of moral condemnation...

The scene is repeated on an even more tragic mode in Tess of the d'Urbervilles. Indeed Angel's reaction to Tess's confession of her "seduction" by Alec appears as a sudden syncope - a suspension of meaning followed by a violent outburst that cuts Tess to the quick.

He paused [...] then suddenly broke into horrible laughter - as unnatural and ghastly as a laugh in hell.

'Don't - don't! It kills me quite, that!' she shrieked. 'o have mercy upon me - have mercy’ (Hardy 1991, 179; my emphasis)

FATHOM, 3 | 0000 

spontaneous and most desperate reaction in the gripping instants when he suddenly realises his own powerlessness in the face of the whims of Fate. It comes at the very moment when all his powers of derision are brutally overwhelmed by the feeling of the absurd. And Hardy's gargoyle crystallises all these impressions: that of the insignificance of man, and that of the consequent empowerment of a cold, unfeeling universe that at times turns into an active persecutor.

\section{BIBLIOGRAPHY}

Beatty, C. J. P., The Architectural Notebook of Thomas Hardy, Dorchester: Dorset Natural History \& Archaeological Society, 1966.

Beatty, C. J. P., Thomas Hardy's Career in Architecture (1856-1872), Dorchester: Dorset Natural History \& Archaeological Society, 1978.

Bullen, J. B., The Expressive Eye: Fiction and Perception in the Work of Thomas Hardy, Oxford: Clarendon Press, 1986.

Carpenter, Richard C., “Thomas Hardy's ‘Gurgoyles”, Modern Fiction Studies 6.3 (Autumn 1960): 223-232.

Hamon, Philippe, Du Descriptif, Paris: Hachette Supérieur, 1993.

FATHOM, 3 | 0000 
Hardy, Thomas, Jude the Obscure (1895), ed. Norman Page, New York \& London: Norton, 1978. (Jude )

Hardy, Thomas, Far from the Madding Crowd (1874), ed. Robert C. Schweik, New York \& London: Norton, 1986.

Hardy, Thomas, The Life and Work of Thomas Hardy, ed. Michael Millgate, London: Macmillan, 1989.

Hardy, Thomas, Tess of the d'Urbervilles (1892), ed. Scott Elledge, New York \& London: Norton, 1991. (Tess)

Hardy, Thomas, Thomas Hardy's Public Voice: The Essays, Speeches and Miscellaneous Prose, ed. Michael Millgate, Oxford \& New York: Oxford University Press, 2001.

Hardy, Thomas, The Return of the Native (1878), ed. Phillip Mallett, New York \& London: Norton, 2006. $(R N)$

Hervoche-Bertho, Brigitte, “Seminal Gothic Dissemination in Hardy's Writings”, Victorian Literature and Culture 29.2 (2001): 451-467.

Millgate, Michael, “Thomas Hardy's Library at Max Gate: Catalogue of an Attempted Reconstruction" [Online] http://www.library.utoronto.ca/fisher/hardy/hardycataz.html (last accessed 3 Mar 2011).

Millgate, Michael, Thomas Hardy: A Biography, Oxford: OUP, 1985.

Ruskin, John, The Stones of Venice (1851-1853), New York: John Wiley and Sons, 1891. (SV)

Ruskin, John, The Seven Lamps of Architecture (1849/1880), New York: Dover Publications, 1989. ( SLA)

Scott, James F., “Thomas Hardy's Use of the Gothic: An Examination of Five Representative Works", Nineteenth-Century Fiction 17.4 (March 1963): 363-380.

Seymour-Smith, Martin, Hardy, New York: Saint Martin's Press, 1994.

Tomalin, Claire, Thomas Hardy: The Time-Torn Man, London: Penguin Books, 2006.

Zabel, Morton Dauwen, "Hardy in Defense of his Art: The Aesthetics of Incongruity", Southern Review 6.1 (Summer 1940): 125-149.

\section{ABSTRACTS}

Focusing on the famous description of the gargoyle of the Weatherbury Church in Far from the Madding Crowd, chapter 46, this paper looks into the possible, yet little acknowledged, sources of Hardy's treatment of the gothic and the grotesque-notably in relation with John Ruskin's developments on the subject in The Seven Lamps of Architecture (1849) and The Stones of Venice (1851-53). From there it goes on to show that the awful distorted grin of the gargoyle is far more than a merely decorative motif: on the contrary it is used throughout Hardy's novels to subtend a reflexion on cosmic indifference and the irony of Fate - since Fate is consistently shown as laughing sardonically upon men's decisions and troubles.

Cet article prend pour point de départ la célèbre description de la gargouille de l'église de Weatherbury, au chapitre 46 de Far from the Madding Crowd, pour proposer un rapprochement entre le traitement du style gothique et de ses motifs grotesques chez Hardy, et les développements de John Ruskin sur le sujet. Le sourire atroce et déformé de la gargouille se révèle cependant être bien plus qu'un simple motif décoratif : il est la base d'une réflexion 
cohérente sur l'indifférence du cosmos et la cruauté du Destin-un Destin dont les sentences résonnent dans les romans de Hardy sous la forme presque systématique d'un ricanement sardonique.

\section{INDEX}

Mots-clés: architecture, Ruskin (John), destin, gothique, grotesque, hybridité, rire, ornement Keywords: fate, Gothic art, hybridity, laughter, ornament

\section{AUTHOR}

\section{ISABELLE GADOIN}

Isabelle Gadoin is Professor at the University of Poitiers, where she teaches English literature and text-and-image studies. Her thesis was entitled "Structures spatiales dans les romans de 'Caractère et d'Environnement' de Thomas Hardy: espace représenté et espace représentant" (University Paris 3 - Sorbonne Nouvelle, 1993); she has been one of the promoters of Hardy studies in France, and was one of the founding members of FATHOM (French Association for Thomas Hardy Studies). Her research bears on the question of space and visual structures in the work of Thomas Hardy, and more globally on visual perception and the relationships between text and image in literary works. She has recently published Far from the Madding Crowd: Thomas Hardy, entre convention et subversion (Paris : CNED, 2010) as well as various articles on Far from the Madding Crowd, in the academic journals Cycnos, Études Anglaises and in the online journal E-Crini (University of Nantes). 